\title{
Studies of Nucleosides and Nucleotides. LII.1) Purine Cyclonucleosides. (17). Synthesis and Properties of Cyclonucleosides derived from Inosine and Thioinosine
}

\author{
Morio IKehara and Masako MUraoka ${ }^{2 a)}$ \\ Faculty of Pharmaceutical Sciences, Osaka University ${ }^{2)}$ and Department of Chemistry, \\ Japan Women's University ${ }^{2 a)}$
}

(Received October 1, 1971)

\begin{abstract}
$8,2^{\prime}$-Anhydro- 8 -mercapto- 9 - $\beta$-D-arabinofuranosyladenine (I), $\quad 8,3^{\prime}$-anhydro- 8 -mercapto-9- $\beta$-D-xylofuranosyladenine (II) and $8,5^{\prime}$-anhydro-8-mercapto-9- $\beta$-D-ribofuranosyladenine (III) were deaminated with barium nitrite in acetic acid to give the corresponding S-cycloinosines (IV-VI). These cyclonucleosides had characteristic properties in ultraviolet (UV), nuclear magnetic resonance (NMR), circular dichroism (CD) and mass spectra, which were as expected from those of adenosine cyclonucleosides. Compounds IV-VI were benzoylated on sugar $\mathrm{OH}$ groups and subjected to thiolation reaction using phosphorus pentasulfide in pyridine containing water. Deprotection either with sodium methoxide or ammonia in methanol gave $8,2^{\prime}$-anhydro-6,8-dimercapto- 9 - $\beta$ - $\mathrm{D}$-arabinofuranosylpurine (XVI), 8,3'-anhydro-6,8-dimercapto-9- $\beta$-D-xylofuranosylpurine (XVII) and $8,5^{\prime}$-anhydro-6,8-dimercapto-9- $\beta$-D-ribofuranosylpurine (XVIII), respectively. The structure of these cyclonucleosides was confirmed by their characteristic UV, CD, NMR and mass spectra. 6-Mercaptopurine cyclonucleosides were easily oxidized to form disulfides by air oxidation or iodine treatment.
\end{abstract}

6-Mercaptopurine is one of the drugs extensively used in cancer chemo-therapy. ${ }^{\mathbf{3} 4)}$ Thioinosine, a nucleoside of 6-mercaptopurine, is also known to have a good therapeutic effect.5) In recent years we synthesized a number of purine 8-cyclonucleosides and showed that in each cyclonucleoside the base and the sugar moieties are fixed at defined angles by means of an anhydro linkage so that they show different physical properties in ultraviolet (UV), nuclear magnetic resonance (NMR) and circulardichroism (CD) spectra. ${ }^{6}$ In this paper we report the synthesis and properties of 6 -mercaptopurine cyclonucleosides bearing $8,2^{\prime}-, 8,3^{\prime}$ and $8,5^{\prime}$-S-anhydro linkages. In the course of synthesis, we also have obtained inosine cyclonucleosides and some physical properties of these cyclonucleosides are described.

For our present experiments we used the previously described $8,2^{\prime}-, 8,3^{\prime}$ - and $8,5^{\prime}$-Scyclonucleosides derived from adenosine ${ }^{7)}$ as starting materials. When $8,2^{\prime}$-anhydro-8-mercapto-9- $\beta$-D-arabinofuranosyladenine $\left(8,2^{\prime}\right.$-S-cycloadenosine) (I) was treated with barium nitrite in $2 \mathrm{~N}$ acetic acid at room temperature, deamination proceeded almost quantitatively within $24 \mathrm{hr}$ and 8,2'-anhydro-8-mercapto-9- $\beta$-D-arabinofuranosylhypoxanthine $\left(8,2^{\prime}\right.$-cycloinosine) (IV) was obtained in a yield of $76 \%{ }^{8}$ ) In the case of $8,3^{\prime}$-anhydro-9- $\beta$-D-xylofuranosyladenine $\left(8,3^{\prime}-\mathrm{S}\right.$-cycloadenosine) (II), the deamination reaction proceeded similarly and the product $8,3^{\prime}$-anhydro-8-mercapto-9- $\beta$-D-xylofuranosylhypoxanthine $\left(8,3^{\prime}\right.$-S-cycloinosine (V) was obtained in a yield of $77 \%$. However, in the case of $8,5^{\prime}$-anhydro-8-mercaptoadenosine

1) Part LI of this series: M. Ikehara and H. Morisawa, Chem. Pharm. Bull. (Tokyo), 19, 2593 (1971).

2) Location: Toyonaka, Osaka; a) 2-8-1, Mejirodai, Bunkyo-ku, Tokyo.

3) G.H. Hitchings and C.P. Rhoads, Am. N. Y. Acad. Sci., 60, 183 (1954).

4) M.R. Atkinson and A.W. Murry, Biochem. J., 94, 64 (1965).

5) J.J. Fox, I. Wempen, A. Hampton and I.L. Doerr, J. Am. Chem. Soc., 80, 1669 (1959).

6) M. Ikehara, Accounts of Chem. Res., 12, 47 (1969).

7) M. Ikehara and M. Kaneko, Tetrahedron, 24, 4251 (1970).

.8) This specimen was identical with a sample synthesized from 8-mercapto-inosine (A. Yamazaki unpublished experiments). 


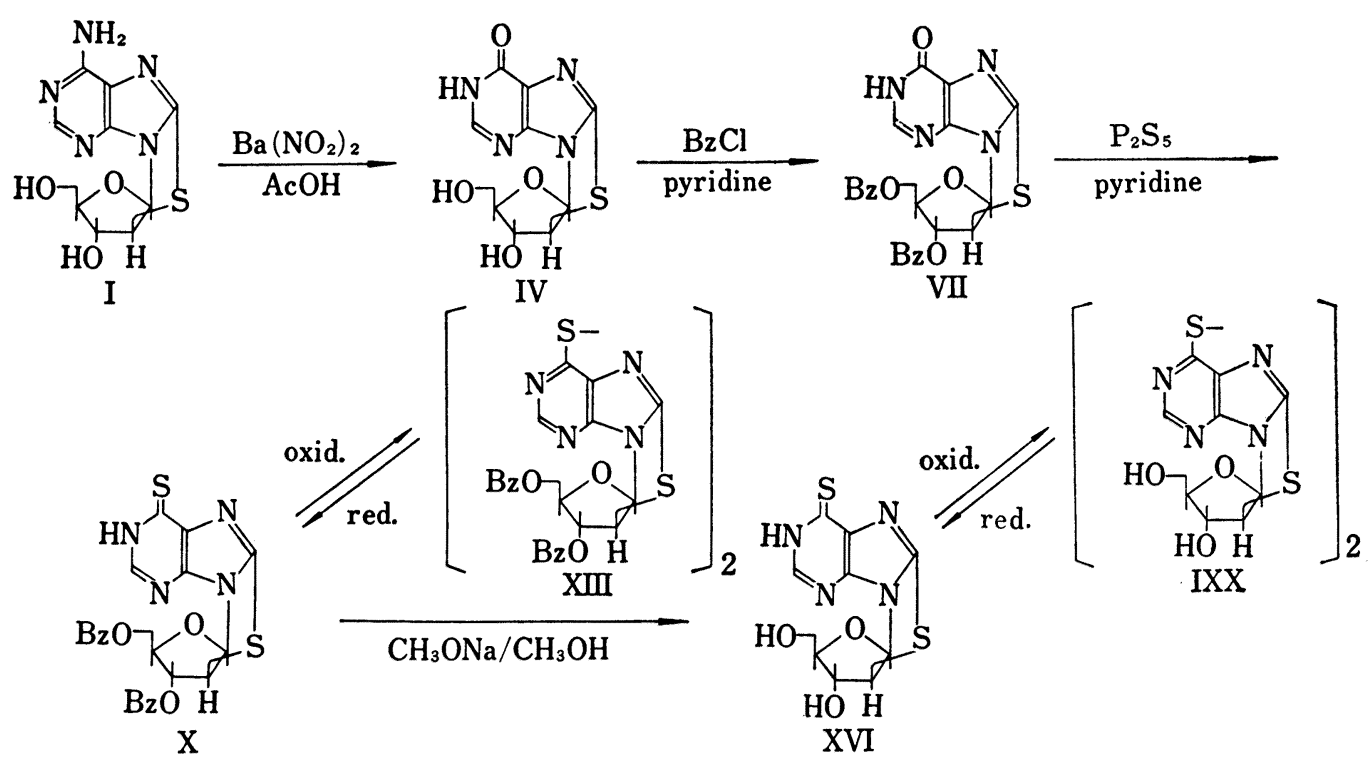

Chart 1<smiles>CC(Br)(C(=O)O)C(=O)O</smiles>

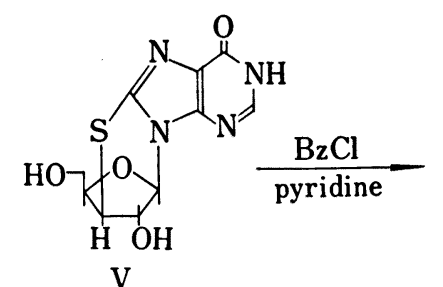

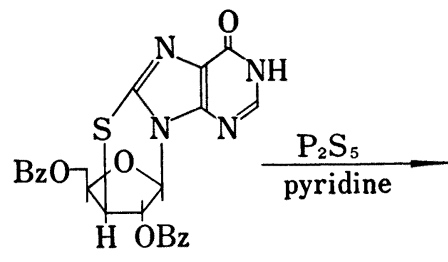

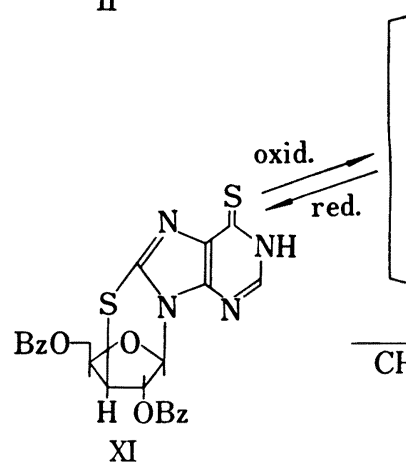

VIII

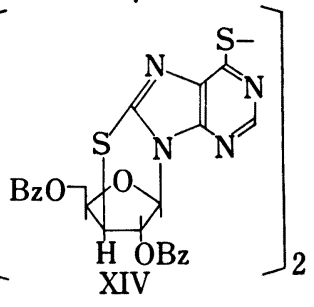
$\mathrm{HO}$

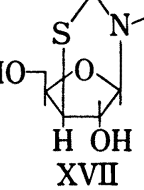

Chart 2

(8,5'-S-cycloadenosine) (III), the reaction proceeded rather slowly and 6 days were required for the completion of the reaction. Compound VI was obtained as colorless crystals in a yield of $73 \%$.

As shown in Table I, UV absorption maxima of the cyclonucleosides (IV, V and VI) shifted bathochromically from 8,2'- to 8,3'- and 8,5'-derivatives. Especially in alkaline conditions the maxima shifted $3-11 \mathrm{~nm}$ from $8,2^{\prime}$ - to $8,5^{\prime}$-cyclonucleoside and the shoulder on both sides of the maximum sharpened in 8, $3^{\prime}$ - and 8,5'-cyclonucleosides. These features were well consistent with those observed in the case of adenine cyclonucleosides ${ }^{4}$ ) and may be caused 


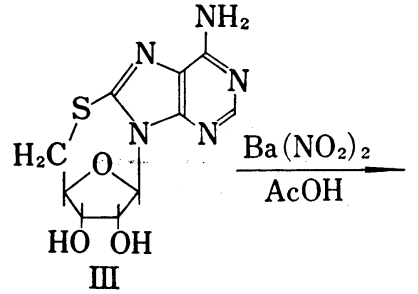

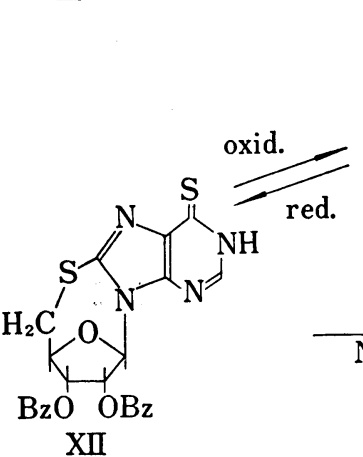

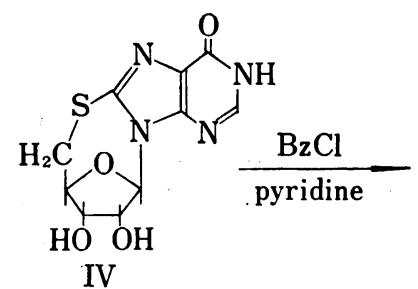

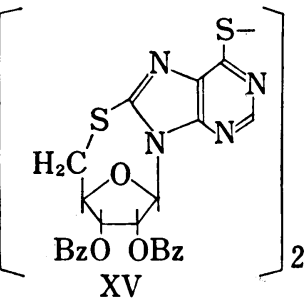

$\mathrm{NH}_{3} / \mathrm{CH}_{3} \mathrm{OH}$

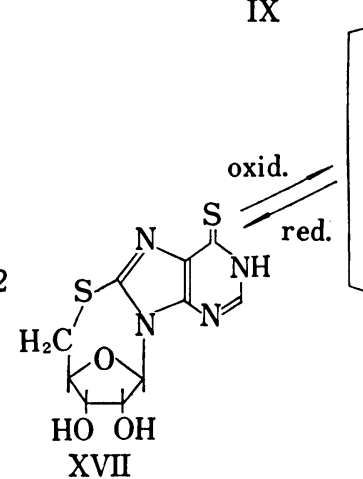

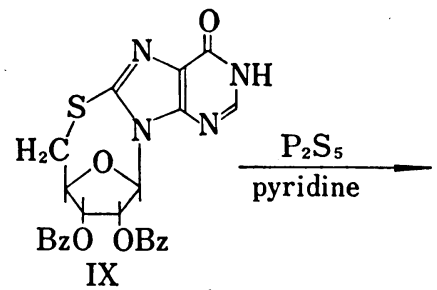

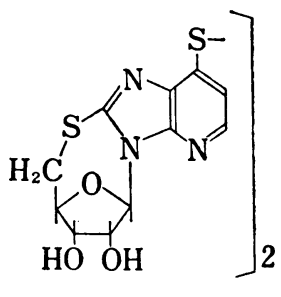
$\mathrm{XXI}$

Chart 3

TABLE I. UV and CD Spectra of S-Cycloinosines and Thioinosines

\begin{tabular}{|c|c|c|c|c|c|c|c|}
\hline & \multicolumn{3}{|c|}{$\mathrm{UV} \max (\mathrm{nm})$} & \multicolumn{4}{|c|}{$\left.\mathrm{CD}^{a}\right)$} \\
\hline & $\mathrm{H}^{+}$ & $\mathrm{H}_{2} \mathrm{O}^{a)}$ & $\mathrm{OH}^{-}$ & peak $(\mathrm{nm})$ & {$[\theta]$} & trough $(\mathrm{nm})$ & {$[\theta]$} \\
\hline $8,2^{\prime}$-S-Cycloinosine & 266 & 266 & $\begin{array}{l}269.5 \\
287(\mathrm{sh})\end{array}$ & 270 & 5300 & 213 & -3800 \\
\hline $8,3^{\prime}$-S-Cycloinosine & 271.5 & 271 & $\begin{array}{l}281 \\
273(\mathrm{sh}) \\
293(\mathrm{sh})\end{array}$ & 271 & 12500 & 215 & -20100 \\
\hline 8,5'-S-Cycloinosine & $\begin{array}{l}273 \\
280(\mathrm{sh})\end{array}$ & $\begin{array}{l}273 \\
280(\mathrm{sh})\end{array}$ & $\begin{array}{l}284 \\
274(\mathrm{sh}) \\
295 \text { (sh) }\end{array}$ & 272 & 22600 & 233 & -34900 \\
\hline $8,2^{\prime}-\mathrm{S}-\mathrm{C}$ yclothioinosine & $\begin{array}{l}336 \\
251.5\end{array}$ & $\begin{array}{l}322.5 \\
249.5\end{array}$ & $\begin{array}{l}320.5 \\
249.5\end{array}$ & 322 & 10800 & 249 & -26900 \\
\hline 8,3'-S-Cyclothioinosine & $\begin{array}{l}338.5 \\
329(\mathrm{sh}) \\
256\end{array}$ & $\begin{array}{l}327 \\
339(\mathrm{sh}) \\
255\end{array}$ & $\begin{array}{l}325.5 \\
314(\mathrm{sh}) \\
257\end{array}$ & 327 & 23600 & 258 & -33900 \\
\hline $8,5^{\prime}$-S-Cyclothioinosine & $\begin{array}{l}338.5 \\
329(\mathrm{sh}) \\
260\end{array}$ & $\begin{array}{l}329 \\
338(\mathrm{sh}) \\
259.5\end{array}$ & $\begin{array}{l}319(\mathrm{sh}) \\
326 \\
259.5\end{array}$ & 329 & 33500 & 258 & -73700 \\
\hline
\end{tabular}

a) 0.01 mole phosphate buffer $\mathrm{pH} 7.0$

by the formation of sterically distorted $5-7$ membered rings fused to $8-9$ position of hypoxanthine.

CD spectra of the cyclonucleosides, (IV, V and VI) are shown in Table I and Fig. 1. Amplitudes of Cotton effects of these compounds are definitely small compared to those of adenine cyclonucleosides $^{4}$ ) and the order of magnitude was $8,2^{\prime}-<8,3^{\prime}-<8,5^{\prime}$-cyclonucleosides as expected. Here again a general rule ${ }^{9)}$ of the relationship between torsion angle ${ }^{10}$ and the magnitude of Cotton effect was confirmed. All these CD curves showed a positive Cotton effect at $265-270 \mathrm{~nm}$ corresponding to the main absorption band. Since inosine has a small

9) M. Ikehara, M. Kaneko, Y. Nakahara, S. Yamada and S. Uesugi, Chem. Pharm. Bull. (Tokyo), 19, 1381 (1971).

10) J. Donohue and K.N. Trueblood, J. Mol. Biol., 2, 363 (1960). 
TABLE II. NMR Spectra of S-Cycloinosines and Thioinosines

\begin{tabular}{|c|c|c|c|c|}
\hline & \multicolumn{4}{|c|}{ NMR } \\
\hline & $\mathrm{C}-2-\mathrm{H}(\mathrm{ppm})$ & $J(\mathrm{~Hz})$ & $\mathrm{C}-1^{\prime}-\mathrm{H}(\mathrm{ppm})$ & $J 1^{\prime}-2^{\prime}(\mathrm{Hz})$ \\
\hline $8,2^{\prime}-\mathrm{S}-\mathrm{C}$ ycloinosine & 7.96 (singlet) & 0 & 6.52 (doublet) & 6.6 \\
\hline $8,3^{\prime}-\mathrm{S}-\mathrm{C} y$ cloinosine & 7.97 (singlet) & 0 & 5.79 (singlet) & 0 \\
\hline $8,5^{\prime}-\mathrm{S}-\mathrm{C}$ ycloinosine & 8.07 (singlet) & 0 & 6.16 (doublet) & 1.4 \\
\hline $8,2^{\prime}-\mathrm{S}-\mathrm{C}$ yclothioinosine & 8.10 (doublet) & 4 & 6.57 (doublet) & 6.0 \\
\hline $8,3^{\prime}$-S-Cyclothioinosine & 8.11 (doublet) & 3 & 5.80 (singlet) & 0 \\
\hline $8,5^{\prime}-\mathrm{S}-\mathrm{C}$ yclothioinosine & 8.22 (singlet) & 0 & 6.13 (singlet) & 0 \\
\hline
\end{tabular}

negative Cotton effect in this region, ${ }^{11)}$ inversion of the sign was consistent with the fact that formation of the cyclonucleoside changed the sign of the Cotton effect. These features supported that these compounds have cyclonucleoside structure.

Comparison of NMR spectra of compound IV, V and VI (Table II) showed a low field shift of signals of H-2 from $7.96 \mathrm{ppm}$ for 8,2'-, $7.97 \mathrm{ppm}$ for 8,3'- and $8.07 \mathrm{ppm}$ for 8,5'-cyclonucleoside. Anomeric protons appeared at 5.79-6.16 ppm and the coupling constants $J_{\mathbf{1}^{\prime}-\mathbf{2}^{\prime}}$ were $6.6 \mathrm{~Hz}$ for $8,2^{\prime}$ - and very small for $8,3^{\prime}$ - and $8,5^{\prime}$-cyclonucleosides. These properties were as expected from those of adenine cyclonucleosides ${ }^{4)}$ and suggested the structure of these cycloinosines to be correct.
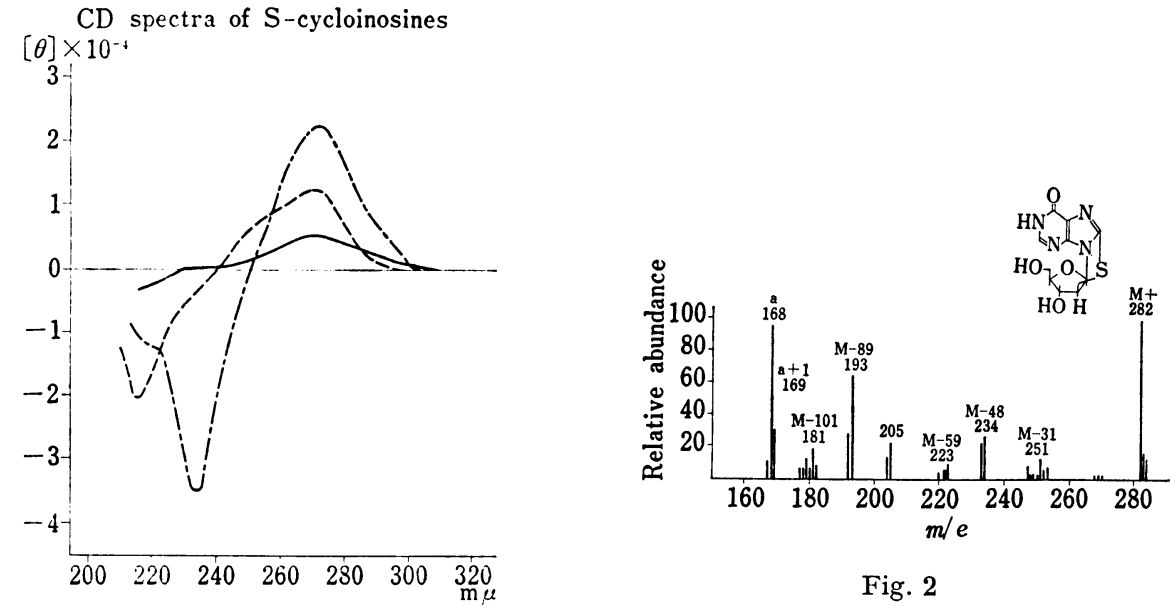

Fig. 1. CD spectra of S-cycloinosines

Fig. 2

$$
\begin{aligned}
& 0.01 \mathrm{м} \text { phosphate buffer } \mathrm{pH} 7.0 \\
& \hline--0-: 8,2^{\prime} \text {-S-cyclo } \\
& \hline- \text {-S-cyclo }
\end{aligned}
$$

Mass spectra of compounds IV, V and VI were listed in Table III and that of IV was shown in Fig. 2. In the spectra of $8,2^{\prime}-(\mathrm{IV})$ and $8,3^{\prime}-(\mathrm{V})$ cyclonucleosides, molecular ion peaks appeared as the most intensive peak, but in $8,5^{\prime}$-cyclonucleoside (VI) it appeared as the second highest peak next to the peak a corresponding to 8-mercatohypoxanthine ion. In compound IV and $\mathrm{V}$, peak a appeared as the second intense peak. M-31 (m/e 251, $\left.\mathrm{M}-\mathrm{CH}_{2} \mathrm{OH}\right) \mathrm{M}-59$ $\left(m / e\right.$ 223, $\left.\mathrm{M}_{-} \mathrm{C}_{2} \mathrm{H}_{3} \mathrm{O}_{2}\right)$ and $\mathrm{M}-77\left(\mathrm{~m} / \mathrm{e} 205, \mathrm{M}-\left(\mathrm{C}_{2} \mathrm{H}_{3} \mathrm{O}_{2} \mathrm{H}_{2} \mathrm{O}\right)\right)$ ions appeared as expected from the fragmentation pattern of adenine cyclonucleosides. ${ }^{12)}$ The same type of fragmentation was observed also in the case of dimethyladenine cyclonucleosides.1) The peak corre-

11) D.W. Miles, R.K. Robins and H. Eying, J. Phys. Chem., 172, 3931 (1967).

12) M. Ikeda, Y. Tamura and M. Ikehara, J. Heterocycl. Chem., 7, 1377 (1970). 
TABle III. Principal Mass Spectral Peaks in the Spectra (70 ev) of $8,2^{\prime}, 8,3^{\prime}, 8,5^{\prime}$-SCycloinosines and Thioinosines ( $\%$ relative abundance)

\begin{tabular}{|c|c|c|c|c|c|c|c|c|c|}
\hline Compound & $\mathrm{M}^{+}$ & M-31 & $\mathrm{M}-48$ & M-59 & M-77 & M-89 & M-101 & $a+1$ & $a^{a)}$ \\
\hline $8,2^{\prime}$-S-Cycloinosine & $\begin{array}{c}282 \\
(100)\end{array}$ & $\begin{array}{l}251 \\
(13)\end{array}$ & $\begin{array}{l}234 \\
(26)\end{array}$ & $\begin{array}{c}223 \\
(8)\end{array}$ & $\begin{array}{c}205 \\
(8)\end{array}$ & $\begin{array}{l}193 \\
(64)\end{array}$ & $\begin{array}{l}181 \\
(18)\end{array}$ & $\begin{array}{l}169 \\
(30)\end{array}$ & $\begin{array}{l}168 \\
(95)\end{array}$ \\
\hline $8,3^{\prime}$-S-Cycloinosine & $\begin{array}{c}282 \\
(100)\end{array}$ & $\begin{array}{c}251 \\
(3)\end{array}$ & $\begin{array}{c}234 \\
(3)\end{array}$ & $\begin{array}{c}223 \\
(9)\end{array}$ & $\begin{array}{c}205 \\
(6)\end{array}$ & $\begin{array}{l}193 \\
(28)\end{array}$ & $\begin{array}{c}181 \\
(7)\end{array}$ & $\begin{array}{l}169 \\
(29)\end{array}$ & $\begin{array}{l}168 \\
(79)\end{array}$ \\
\hline $8,5^{\prime}$-S-Cycloinosine & $\begin{array}{l}282 \\
(51.4)\end{array}$ & & & $\begin{array}{c}223 \\
(2)\end{array}$ & & $\begin{array}{l}193 \\
(24)\end{array}$ & $\begin{array}{r}181 \\
(3)\end{array}$ & $\begin{array}{l}169 \\
(56)\end{array}$ & $\begin{array}{c}168 \\
(100)\end{array}$ \\
\hline $8,2^{\prime}-\mathrm{S}-$ Cyclothioinosine & $\begin{array}{c}298 \\
(100)\end{array}$ & $\begin{array}{r}267 \\
(5.5)\end{array}$ & $\begin{array}{l}250 \\
(57)\end{array}$ & $\begin{array}{c}239 \\
(5)\end{array}$ & $\begin{array}{l}221 \\
(11)\end{array}$ & $\begin{array}{l}209 \\
(29)\end{array}$ & $\begin{array}{l}197 \\
(21)\end{array}$ & $\begin{array}{l}185 \\
(15)\end{array}$ & $\begin{array}{l}184 \\
(43)\end{array}$ \\
\hline $8,3^{\prime}-\mathrm{S}-\mathrm{Cyclothioinosine}$ & $\begin{array}{c}298 \\
(100)\end{array}$ & $\begin{array}{c}267 \\
(4)\end{array}$ & $\begin{array}{c}250 \\
(4)\end{array}$ & $\begin{array}{c}239 \\
(7)\end{array}$ & $\begin{array}{c}221 \\
(5)\end{array}$ & $\begin{array}{l}209 \\
(17)\end{array}$ & $\begin{array}{c}197 \\
(7)\end{array}$ & $\begin{array}{l}185 \\
(43)\end{array}$ & $\begin{array}{l}184 \\
(98)\end{array}$ \\
\hline $8,5^{\prime}$-S-Cyclothioinosine & $\begin{array}{l}298 \\
(52.5)\end{array}$ & & & $\begin{array}{c}239 \\
(4)\end{array}$ & $\begin{array}{c}221 \\
(2)\end{array}$ & $\begin{array}{l}209 \\
(13)\end{array}$ & $\begin{array}{c}197 \\
(4)\end{array}$ & $\begin{array}{l}185 \\
(55)\end{array}$ & $\begin{array}{c}184 \\
(100)\end{array}$ \\
\hline
\end{tabular}

a) This ion corresponds to 8-mercapto derivatives.

sponding to M-48 ion ( $m / e$ 234) was observed only in the case of $8,2^{\prime}$-cyclonucleoside (IV). The occurence of this peak suggested the loss of $5^{\prime}-\mathrm{CH}_{2} \mathrm{OH}$ and $3^{\prime}-\mathrm{OH}$ from the furanose ring. This fragmentation was consistent with that observed in $8,2^{\prime}$-cycloadenosine and supported the structure of IV to be a $8,2^{\prime}$-cyclonucleoside.

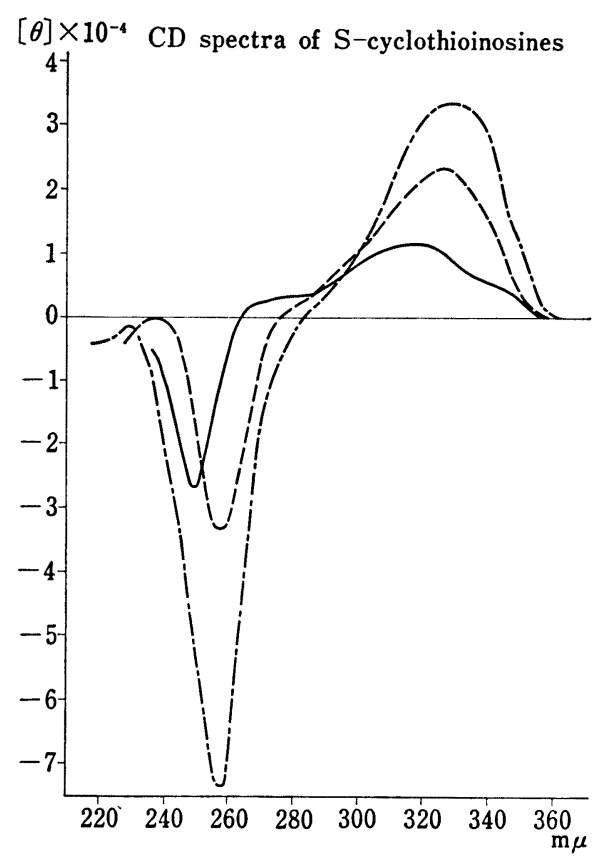

Fig. 3

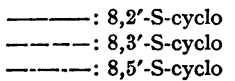

The cyclonucleosides (IV, V and VI), thus obtained, were subjected to thiolation at 6-position. According to the thiolation procedure of Fox, et al. ${ }^{5)}$ these cyclonucleosides were benzoylated to protect sugar $\mathrm{OH}$ groups. Usual benzoylation using 2.8 equivalents of benzoyl chloride in pyridine at $40-50^{\circ}$ for $5 \mathrm{hr}$ gave benzoylated derivatives (VII-IX) in $60-63 \%$ yields.

For the thiolation reaction of benzoylated inosine and guanosine, Fox, et al. used phosphorus pentasulfide in refluxing pyridine in the presence of $3.4-8$ molar equivalents of water.

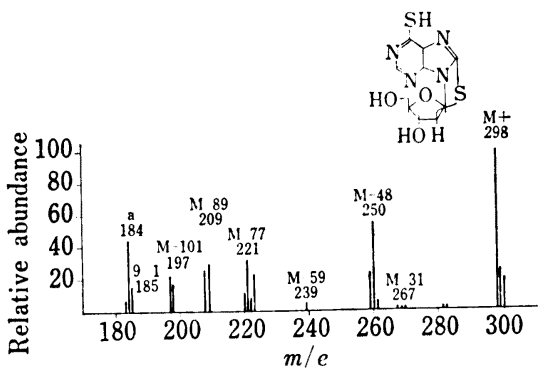

Fig. 4

We examined this procedure precisely and found that in case of the thiolation of benzoylated cycloinosines (VII, VIII and IX), yields were nearly quantitative by using four equivalents of water. Refluxing the reaction mixture for $6 \mathrm{hr}$ and the. appropriate work-up procedure gave crystalline benzoylated thioinosine cyclonucleosides (X, XI and XII) in yields of $76-86 \%$. Recrystallization of these compounds was performed from methanol containing a small amount of 2 -mercaptoethanol, because these compounds were readily convertible to corresponding 
disulfides due to air oxidation. This oxidation reaction was further confirmed by the oxidation with iodine and resulting disulfides (XIIIa, XIVa and XVa) were isolated by thin-layer chromatography using chloroform-ethanol (19:1, vol./vol.) mixture. Disulfides XIIIa-XVa could be reduced back to mercapto compounds with sodium hyposulfate or 2-mercaptoethanol. The structure of benzoyl cyclothioinosines was confirmed by elemental analysis and UV absorption properties having $\lambda$ maxima at around 230 and $336 \mathrm{~nm}$. Disulfides had UV absorption maxima at around 230 and $310 \mathrm{~nm}$.

Debenzoylation of compound $\mathrm{X}$ and $\mathrm{XI}$ was performed by refluxing with $2 \mathrm{~N}$ sodium methoxide in methanol for $2 \mathrm{hr}$. In the case of 8,5'-cyclonucleoside (XII), more mild methanolammonia was employed, because it decomposed by the treatment with sodium methoxide. Since the resulting thiocycloinosines (XVI, XVII and XVIII) were also susceptible to airoxidation, recrystallization was performed from water containing a small amount of thiosulfate. $8,2^{\prime}-(\mathrm{XVI}), 8,3^{\prime}$-(XVII) and 8,5'-cyclothioinosine (XVIII) were obtained as pure samples yields of $79-90$ and $80 \%$, respectively.

As shown in Table I, UV absorption maxima of these thiocycloinosines exist at 322,5-329 $\mathrm{nm}$ in neutral condition and a bathochromic shift from 8,2'-(XVI), 8, $3^{\prime}$-(XVII) to 8,5'-cyclonucleosides (XVIII) were observed as in the case of cycloionosines. However, in compounds XVI-XVIII $\lambda$ max's in alkaline condition shifted $c a .3 \mathrm{~nm}$ hypsochromically and second peaks appeared at $250-260 \mathrm{~nm}$ region. This may be explained by the splitting of absorption bands due to dissociation of $-\mathrm{SH}$.

$\mathrm{CD}$ spectra (Fig. 3) of compounds XV-XVII showed large positive Cotton bands at around $340 \mathrm{~nm}$ in the order of magnitude, $8,2^{\prime}-<8,3^{\prime}-<8,5^{\prime}$-cyclonucleosides. Negative bands at around $250-260 \mathrm{~nm}$ also showed this order. These features are consistent with those observed in other cyclonucleosides of adenine ${ }^{9)}$ and $\mathrm{N}^{\mathbf{6}}$-dimethyladenine. ${ }^{\mathbf{1}}$

NMR spectra of thiocycloinosine (XVI-XVIII) were shown in Table II. The most characteristic feature is that signals of $\mathrm{C}_{2}-\mathrm{H}$ appeared as doublets centered at $8.10-8.11 \mathrm{ppm}$ having $J=3-4 \mathrm{~Hz}$. This splitting may be due to coupling of $\mathrm{C}_{2}-\mathrm{H}$ to $\mathrm{N}_{1}-\mathrm{H}$, which could not be observed in the case of inosine cyclonucleosides because of a rapid tautomeric exchange between - $\mathrm{CO}-\mathrm{NH}$ - and $-\mathrm{C}(\mathrm{OH})=\mathrm{N}$-. The coupling constant of $\mathrm{H}_{\mathbf{1}^{\prime}}$ and $\mathrm{H}_{2^{\prime}}$ in 8,2'-cyclonucleoside $(\mathrm{XVI})$ was $6.0 \mathrm{~Hz}$ and suggested the $\mathrm{C}_{\mathbf{2}^{\prime}}$-endo conformation. Those of 8,3'- and 8,5'-

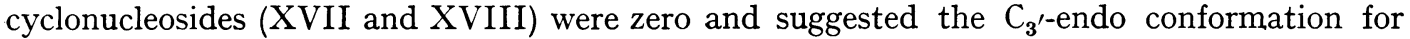
these cyclonucleosides. These features are again consistent with those observed in adenine cyclonucleosides. ${ }^{4)}$

Finally, mass spectra of cyclonucleosides (XVI-XVIII) were taken. As shown in Fig. 4 and Table III, the molecular ion peak appeared as most intensive peaks in $8,2^{\prime}-$ and $8,3^{\prime}$ cyclonucleosides. However, in $8,5^{\prime}$-cyclonucleoside an ion corresponding to 6,8-dimercapto purine appeared most strongly. Other fragmentation pattern was as expected from the case of other cyclonucleosides as described above. M-48 peak appeared only in the case of 8,2'cyclonucleoside and supported the structure of compound (XVI) to be correct.

Biological properties of these cyclonucleosides are under investigation and will be reported in futural publication.

\section{Experimental $\left.{ }^{13}\right)$}

8,2'-Anhydro-8-mercapto-9- $\beta$-D -arabinofuranosylhypoxanthine $-8,2^{\prime}$ - Anhydro-8-mercapto-9- $\beta$-D-arabinofuranosyladenine $\left.{ }^{7}\right)(281 \mathrm{mg}, 1.0 \mathrm{mmole})$ was dissolved in $2 \mathrm{~N}$ acetic acid $(20 \mathrm{ml})$. Into the solution

13) UV absorption spectra were measured with a Hitachi EPS-3T spectrophotometer, IR sepctra with a Hitachi EPI-L spectrophotometer, NMR spectra with a Hitachi H-6013 high resolution spectrometer operated at $60 \mathrm{MHz}$ with TMS as internal standard, and CD spectra with a JASCO ORD/UV-5 spectropolarimeter equipped with a $\mathrm{CD}$ attachment. Paper chromatography was performed in solvent $\mathrm{A}$, water adjusted to $\mathrm{pH} 10$, solvent $\mathrm{B}, n$-butanol-water $(86: 14, \mathrm{v} / \mathrm{v})$, and solvent $\mathrm{C}$, isopropanol-ammoniawater $(7: 1: 2, \mathrm{v} / \mathrm{v})$. 
was added barium nitrite $(560 \mathrm{mg}, 2.3 \mathrm{mmoles})$ dissolved in water $(5 \mathrm{ml})$. Reaction mixture was kept at room temperature for $10 \mathrm{hr}$. After examination of the reaction mixture by TLC on Avicel in solvent A, yellow precipitates were collected by filtration. Into the filtrate was added $1 \mathrm{~N}_{2} \mathrm{SO}_{4}$ (calculated amount to neutralize barium ion). Barium sulfate was removed by centrifugation, filtrate and washings were evaporated in vacuo, and residue combined with precipitates collected before. Recrystallization of this material from water gave pale yellow needles, $(213 \mathrm{mg}, 76 \%)$. Analytical sample was recrystallized further from water, $\mathrm{mp} 263-266^{\circ}$. Anal. Calcd. for $\mathrm{C}_{10} \mathrm{H}_{10} \mathrm{O}_{4} \mathrm{~N}_{4} \mathrm{~S} \cdot 2 \mathrm{H}_{2} \mathrm{O}: \mathrm{C}, 37.74 ; \mathrm{H}, 4.43 ; \mathrm{N}, 17.61$. Found: C, 37.65 ; $\mathrm{H}, 4.27 ; \mathrm{N}, 17.32$. UV absorption properties: $\lambda_{\max }^{\mathrm{pH}} \frac{1}{266 \mathrm{~nm}}(\varepsilon 18700) ; \lambda_{\max }^{\mathrm{pH}} 266 \mathrm{~nm}(\varepsilon 18700) ; \lambda_{\max }^{\mathrm{pH}} 13269.5$ $\mathrm{nm}(\varepsilon 19100), 287 \mathrm{~nm}$ (sh, $\varepsilon$ 9500). PPC: Rf (A) 0.63, Rf (B) $0.18, R f$ (C) 0.36 .

8,3'-Anhydro-8-mercapto-9 - $\beta$-D -xylofuranosylhypoxanthine- $-8,3^{\prime}$ - Anhydro- 8 -mercapto- 9 - $\beta$-D - xylofuranosyladenine $)(281 \mathrm{mg}, 1.0 \mathrm{mmole})$ was dissolved in $2 \mathrm{~N}$ acetic acid $(30 \mathrm{ml})$. Into the solution was added barium nitrite $(560 \mathrm{mg}, 2.3 \mathrm{mmoles})$. The reaction mixture was kept at room temperature for $10 \mathrm{hr}$. $\mathrm{Re}-$ sulting yellow precipitates and the residue obtained by the procedure as above were combined and recrystallized from water. 8,3'-S-Cycloinosine was obtained as colorless needles (217 mg, 77\%). Analytical sample was recrystallized further from water, $\mathrm{mp}>300^{\circ}$. Anal. Calcd. for $\mathrm{C}_{10} \mathrm{H}_{10} \mathrm{O}_{4} \mathrm{~N}_{4} \mathrm{~S}: \mathrm{C}, 42.56 ; \mathrm{H}, 3.57 ; \mathrm{N}$, 19.85. Found: $\mathrm{C}, 42.69 ; \mathrm{N}, 3.38 ; \mathrm{N}, 19.78$. UV absorption properties: $\lambda_{\max }^{\mathrm{PH} 1} 271.5 \mathrm{~nm}(19800) ; \lambda_{\max }^{\mathrm{pH}}$ 271 $\mathrm{nm}(18800) ; \lambda_{\max }^{\mathrm{pH} 13} 281 \mathrm{~nm}(19000), 273 \mathrm{~nm}$ (sh, 18300), $293 \mathrm{~nm}(\mathrm{sh}, 11400) . \quad \mathrm{PPC}: R f(\mathrm{~A}) 0.62, R f(\mathrm{~B}) 0.22$, $R f(C) 0.40$.

8,5'-Anhydro-8- mercapto-9- $\beta$-D - ribofuranosylhypoxanthine- $-8,5^{\prime}$ - Anhydro- 8 - mercapto-9- $\beta$ - D-ribofuranosyladenine $(562 \mathrm{mg}, 2.0 \mathrm{mmoles})$ was dissolved in $2 \mathrm{~N}$ acetic acid $(76 \mathrm{ml})$. Into the solution was added: dropwise a saturated solution of barium nitrite $(1.20 \mathrm{~g}, 4.6 \mathrm{mmoles})$. The reaction mixture was kept at room temperature for 3 days. If the examination of extent of the reaction by TLC showed incomplete deamination, barium nitrite $(312 \mathrm{mg}, 1.2 \mathrm{mmole})$ was added and the mixture was kept at room temperature for further 2-3 days. After completion of the reaction, resulting precipitates were collected by filtration, washed with ice water, and recrystallized from water. Cyclonucleoside was obtained as colorless needles $(414 \mathrm{mg}, 73 \%)$. Analytical sample was further recrystallized from water. This sample melted once at $251-253^{\circ}$ and decomposed at $278-281^{\circ}$. Anal. Calcd. for $\mathrm{C}_{10} \mathrm{H}_{10} \mathrm{O}_{4} \mathrm{~N}_{4} \mathrm{~S} \cdot \mathrm{H}_{2} \mathrm{O}: \mathrm{C}, 40.00 ; \mathrm{H}, 4.03 ; \mathrm{N}, 18.66$. found: C, 40.12; H, 3.57; N, 18.82. UV absorption properties: $\lambda \underset{\max }{\mathrm{pH}} 233 \mathrm{~nm}$ (sh, 5300), $273 \mathrm{~nm}(18200)$, $280 \mathrm{~nm}(\mathrm{sh}, 17300) ; \lambda_{\max }^{\mathrm{pH}} 234.5 \mathrm{~nm}(8700), 273 \mathrm{~nm}(18200), 280$ (sh, 17300); $\lambda_{\max }^{\mathrm{pH}}{ }^{13} 234.5 \mathrm{~nm}(8700), 274$ $\mathrm{nm}$ (sh, 17300), $284 \mathrm{~nm}$ (19200), $295 \mathrm{~nm}$ (sh, 12200). PPC: Rf (A) 0.55, Rf (B) 0.14, Rf (C) 0.30 .

$8,2^{\prime}$-Anhydro-8-mercapto-9- $\beta$ - $\left(3^{\prime}, 5^{\prime}\right.$-di-0-benzoyl-D-arabinofuranosyl) hypoxanthine- $-8,2^{\prime}$-S - Cycloinosine (564 mg, 2 mmoles, dried over $\mathrm{P}_{2} \mathrm{O}_{5}$ at $60^{\circ}$ for $5 \mathrm{hr}$ under $5 \mathrm{~mm} \mathrm{Hg}$ ), obtained as above, was dissolved in anhydrous pyridine $(20 \mathrm{ml}$, distilled with tosyl chloride and stored over molecular seaves). Into this solution was added gradually benzoyl chloride $(0.64 \mathrm{ml}, 5.6 \mathrm{mmoles})$ with stirring at $50^{\circ}$. The reaction mixture was heated at $50^{\circ}$ for $2 \mathrm{hr}, 40^{\circ}$ for $3 \mathrm{hr}$ and finally kept at room temperature for $10 \mathrm{hr}$ with stirring. Pyridine hydrochloride was filtered off, pyridine evaporated in vacuo, and the residual syrup was azeotropically evaporated twice with water. The residue was dissolved in $\mathrm{CH}_{2} \mathrm{Cl}_{2}$ and the solution was washed with $5 \%$ sodium. bicarbonate and water. Drying over sodium sulfate and evaporation of the solvent gave an amorphous. powder, which was recrystallized from methanol. Colorless platelets, $\mathrm{mp} 255-257^{\circ}$ was obtained $(590 \mathrm{mg}$. $60 \%$ ). Anal. Calcd. for $\mathrm{C}_{24} \mathrm{H}_{18} \mathrm{O}_{6} \mathrm{~N}_{4} \mathrm{~S}: \mathrm{C}, 58.77 ; \mathrm{H}, 3.70 ; \mathrm{N}, 11.43$. Found: $\mathrm{C}, 59.05 ; \mathrm{H}, 3.65 ; \mathrm{N}, 11.48$. UV absorption properties: $\lambda_{\max }^{\mathrm{pH}} 232.5 \mathrm{~nm}(30900), 263 \mathrm{~nm}(20800) ; \lambda_{\max }^{\mathrm{MeOH}} 232 \mathrm{~nm}(32000), 266.5(20800)$; $\lambda_{\max }^{\mathrm{pH} 13} 223 \mathrm{~nm}$ (sh, 35800), $268 \mathrm{~nm}(19500)$. PPC: Rf (B) $0.48, R f(\mathrm{C}) 0.71$.

8,3'-Anhydro-8-mercapto-9- $\beta$ - $\left(2^{\prime}, 5^{\prime}\right.$-di-0-benzoyl-D-xylofuranosyl) hypoxanthine-8, 3 -S-Cycloinosine (564 mg, 2 mmoles, well-dried over $\mathrm{P}_{2} \mathrm{O}_{5}$ as above) was dissolved in anhydrous pyridine $(50 \mathrm{ml})$. Benzoyl chloride $(0.64 \mathrm{ml}, 5.6 \mathrm{mmoles})$ was added dropwise into the solution. Heating of the reaction mixture was. performed as in the case of $8,2^{\prime}$-cyclonucleoside and pyridine was evaporated in vacuo. The residue was dissolved in $\mathrm{CH}_{2} \mathrm{Cl}_{2}(80 \mathrm{ml})$ and the solution was washed with $5 \%$ sodium bicarbonate and water. During the washing a crystalline material appeared in $\mathrm{CH}_{2} \mathrm{Cl}_{2}$ layer. Crystals were collected by filtration, the organic layer was separated and evaporated in vacuo. Residue was combined with crystals obtained before and the whole material was recrystallized from methanol Pale yellow needles, $\mathrm{mp} 175-177^{\circ}$, were obtained $(590 \mathrm{mg}, 60 \%)$. Anal. Calcd. for $\mathrm{C}_{24} \mathrm{H}_{18} \mathrm{O}_{6} \mathrm{~N}_{4} \mathrm{~S} \cdot 1 / 2 \mathrm{H}_{2} \mathrm{O} ; \mathrm{C}, 58.09 ; \mathrm{H}, 3.98 ; \mathrm{N}, 11.06$. Found: C, $58.33 ; \mathrm{H}, 3.77 ; \mathrm{N}, 11.13$. UV absorption properties: $\lambda_{\max }^{\mathrm{pH} 1} 231.5 \mathrm{~nm}(37600), 267 \mathrm{~nm}(23020) ; \lambda_{\mathrm{max}}^{\mathrm{MeOH}} 231.5$. $\mathrm{nm}$ (38700), $269 \mathrm{~nm}(23800) ; \lambda_{\mathrm{max}}^{\mathrm{pH} 13} 225 \mathrm{~nm}$ (45200), $273.5 \mathrm{~nm}(22700), 283 \mathrm{~nm}$ (sh, 21500), 29600 (sh, 11100$)$. $\mathrm{PPC}: \operatorname{Rf}(\mathrm{B}) 0.90, R f(\mathrm{C}) 0.73$.

8, 5-Anhydro-8-mercapto-9- $\beta$ - $\left(2^{\prime}, 3^{\prime}\right.$-di-0-benzoyl-D-ribofuranosyl $)$ phyoxanthine- $-8,5^{\prime}$-S-Cycloinosine $(296 \mathrm{mg}, 1.1 \mathrm{mmole})$ was suspended in anhydrous pyridine $(11 \mathrm{ml})$. Benzoyl chloride $(0.35 \mathrm{ml}, 0.31 \mathrm{mmole})$ was added dropwise to the solution. Reaction mixture was heated at $40^{\circ}$ for $5 \mathrm{hr}$ and kept at room temperature for $10 \mathrm{hr}$ with stirring. After completion of the reaction, the mixture was worked up as described: above. $\mathrm{CH}_{2} \mathrm{Cl}_{2}$ extracts were evaporated to give a residue, which was washed with a small amount of cold ether. Recrystallization of the residue from methanol gave pale yellow needles, $(332 \mathrm{mg}, 63 \%)$. Analytical. sample was recrystallized further from methanol, mp $300^{\circ}$. Anal. Calcd. for $\mathrm{C}_{24} \mathrm{H}_{18} \mathrm{O}_{6} \mathrm{~N}_{4} \mathrm{~S}: \mathrm{C}, 58.77 ; \mathrm{H}$, $3.70 ; \mathrm{N}, 11.43 ; \mathrm{S}, 6.54$. Found: $\mathrm{C}, 58.63 ; \mathrm{H}, 3.56 ; \mathrm{N}, 11.32 ; \mathrm{S}, 6.70$. UV absorption properties: $\lambda_{\mathrm{max}}^{\mathrm{PH}} 231$ $\mathrm{nm}(34000), 272 \mathrm{~nm}(19400), 284 \mathrm{~nm}$ (sh, 16000); $\lambda_{\max }^{\mathrm{pH}} \mathrm{z}^{7} 231 \mathrm{~nm}(33000), 271.5 \mathrm{~nm}(19400), 284 \mathrm{~nm}(\mathrm{sh}, 15300)$; 
$\lambda_{\max }^{\mathrm{pR} 13} 229 \mathrm{~nm}(33600), 276 \mathrm{~nm}(\mathrm{sh}, 17500), 286 \mathrm{~nm}(19100), 289 \mathrm{~nm}$ (sh, 12000). PPC: Rf (B) 0.86, Rf (C) 0.73 .

8,2'-Anhydro-6,8-dimercapto-9- $\beta$ - $\left(2^{\prime}, 3^{\prime}\right.$-di-0-benzoyl-D-arabinofuranosyl $)$ purine-Dibenzoyl-8, $2^{\prime}$-Scycloinosine $(490 \mathrm{mg}, 1 \mathrm{mmole})$ was dissolved in pyridine $(20 \mathrm{ml})$. Into this solution was added phosphorus pentasulfide $(888 \mathrm{mg}, 4 \mathrm{mmoles})$ and water $(0.072 \mathrm{ml}, 4 \mathrm{mmoles})$. After refluxing the mixture for $6 \mathrm{hr}$ with stirring, the extent of the reaction was examined by TLC (silica gel, chloroform:ethanol=19: 1, vol/vol). Pyridine was evaporated in vacuo and the residue was poured into hot water. Heating of the solution on a water bath for $30 \mathrm{~min}$ ceased the evolution of hydrogen sulfide gas. Solid material which appeared was collected by filtration, washed repeatedly with hot water until filtrates became colorless, then with ethanolwater ( $5 \mathrm{ml}, 1: 1, \mathrm{vol} / \mathrm{vol})$ and finally with ether. Recrystallization from methanol containing 1 drop of 2-mercaptoethanol gave colorless platelets $(438 \mathrm{mg}, 86 \%)$. Analytical samlpe was recrystallized from

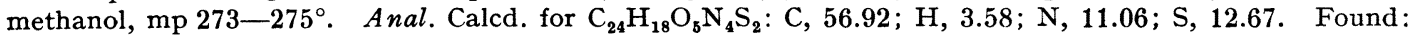
C, 56.64; H, 3.59; N, 11.01; S, 12.27. UV absorption properties: $\lambda_{\max }^{\text {pH } 11} 234 \mathrm{~nm}$ (30600), $242 \mathrm{~nm}$ (sh, 13900), $337 \mathrm{~nm}(27200) ; \lambda_{\max }^{\mathrm{pH}} 232.5 \mathrm{~nm}(36700), 242 \mathrm{~nm}(\mathrm{sh}, 13900), 337 \mathrm{~nm}(27700) ; \lambda_{\mathrm{max}}^{\mathrm{pH} 13} 228.5 \mathrm{~nm}(32900), 251$ $\mathrm{nm}(22300), 326 \mathrm{~nm}(28300)$. PPC: $R f(\mathrm{~B}) 0.77, R f(\mathrm{C}) 0.76$.

8,3'-Anhydro-6,8-dimercapto-9- $\beta$ - $\left(2^{\prime}, 5^{\prime}\right.$-di-0-benzoyl-D-xylofuranosyl $)$ purine_-Dibenzoyl-8, $3^{\prime}$-S-cycloinosine (343 $\mathrm{mg}, 0.7 \mathrm{mmole})$ was dissolved in pyridine $(10 \mathrm{ml})$. Phosphorus pentasulfide $(622 \mathrm{mg}, 2.8 \mathrm{mmoles})$ and water $(0.05 \mathrm{ml}, 2.8 \mathrm{mmole})$ were added to the solution. The reaction mixture was refluxed for $6 \mathrm{hr}$ with stirring. Extent of the reaction was examined by TLC. After the work up procedure as described above, residue was recrystallized from methanol containing 1 drop of 2 -mercaptoethanol. Pale yellow needles

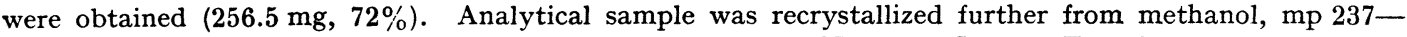
$240^{\circ}$. Anal. Calcd. for $\mathrm{C}_{24} \mathrm{H}_{18} \mathrm{O}_{5} \mathrm{~N}_{4} \mathrm{~S}_{2} \cdot \mathrm{H}_{2} \mathrm{O}: \mathrm{C}, 54.92 ; \mathrm{H}, 3.83 ; \mathrm{N}, 10.68 ; \mathrm{S}, 12.20$. Found: C, 54.71; $\mathrm{H}, 3.92$; $\mathrm{N}, 10.93 ; \mathrm{S}, 12.07$. UV absorption properties: $\lambda_{\max }^{\mathrm{pH}} 232 \mathrm{~nm}(34100), 257 \mathrm{~nm}(\mathrm{sh}, 12000), 340 \mathrm{~nm}(30000)$; $\lambda_{\max }^{p^{7}} 231.5 \mathrm{~nm}(34500), 257 \mathrm{~nm}$ (sh, 11400), $339.5 \mathrm{~nm}$ (30600); $\lambda_{\max }^{\mathrm{pH}}{ }^{18} 228 \mathrm{~nm}$ (30900), $255 \mathrm{~nm}$ (sh, 18800), $328 \mathrm{~nm}(27400)$. PPC: $R f(\mathrm{~B}) 0.83, R f(\mathrm{C}) 0.75$.

8,5'-Anhydro-6,8-dimercapto-9- $\beta$ - $\left(2^{\prime}, 3^{\prime}\right.$-di-0-benzoyl-D-ribofuranosyl) purine-Dibenzoyl-8, $5^{\prime}$-S - cycloinosine ( $245 \mathrm{mg}, 0.5 \mathrm{mmole})$ was dissolved in pyridine $(10 \mathrm{ml})$. Into this solution was added phosphorus pentasulfide (444 mg, $2.0 \mathrm{mmoles})$ and water $(0.036 \mathrm{ml}, 2.0 \mathrm{mmoles})$. Refluxing of the solution for $6 \mathrm{hr}$ with stirring completed the thiolation. Appropriate work up as described above gave a residue, which was recrystallized from methanol containing 1 drop of 2-mercaptoethanol. Dibenzoyl-8,5'-S-cyclothioinosine was obtained as yellow platelets $(205.5 \mathrm{mg}, 82 \%)$. Analytical sample was recrystallized further twice from methanol, mp 196-201 ${ }^{\circ}$. Anal. Calcd. for $\mathrm{C}_{24} \mathrm{H}_{18} \mathrm{O}_{5} \mathrm{~N}_{4} \mathrm{~S}_{2} \cdot 1 / 2 \mathrm{H}_{2} \mathrm{O}: \mathrm{C}, 55.92 ; \mathrm{H}, 3.72 ; \mathrm{N}, 10.87 ; \mathrm{S}, 12.41$. Found: C, 55.82; H, 3.72; N, 11.28; S, 12.49. UV absorption properties: $\lambda_{\max }^{\text {pH }} 229.5 \mathrm{~nm}(33700), 260 \mathrm{~nm}$ $(\mathrm{sh}, 11500), 336 \mathrm{~nm}(29800) ; \lambda_{\max }^{\text {pH }} 230 \mathrm{~nm}(32900), 261 \mathrm{~nm}(\mathrm{sh}, 10300), 336 \mathrm{~nm}(29800) ; \lambda_{\max }^{\text {pH } 13} 227 \mathrm{~nm}(34200)$, $260 \mathrm{~nm}(17500), 330 \mathrm{~nm}(23600)$. PPC: $R f(\mathrm{~B}) 0.89, R f(\mathrm{C}) 0.85$.

8,2'-Anhydro-6,8-dimercapto-9- $\boldsymbol{\beta}$-D-arabinofuranosylpurine-Dibenzoyl-8,2'-cyclothioinosine (152 $\mathrm{mg}$, $0.3 \mathrm{mmole})$ was dissolved in anhydrous methanol $(30 \mathrm{ml})$. Into this solution was added $2 \mathrm{~N}$ sodium methoxide $(0.17 \mathrm{ml})$. The reaction mixture was refluxed for $2 \mathrm{hr}$ with stirring. After completion of the reaction was examined by TLC on Avicel in solvent A, methanol was evaporated in vacuo. The residue was dissolved in water $(30 \mathrm{ml})$ and the water layer was extracted with $\mathrm{CH}_{2} \mathrm{Cl}_{2}(10 \mathrm{ml} \times 3)$. The water layer was evaporated to $c a .5 \mathrm{ml}$, brought to $\mathrm{pH} \mathrm{4-5}$ with $\mathrm{N}$-acetic acid, and kept in a refrigerator. Resulting crystals were collected by filtration and recrystallized from water containing a small amount of sodium thiosulfate. $8,2^{\prime}$-Cyclonucleoside was obtained as colorless platelets $(70.5 \mathrm{mg}, 79 \%)$. Analytical sample was recrystallized further from water, mp 258-262 ${ }^{\circ}$. Anal. Calcd. for $\mathrm{C}_{10} \mathrm{H}_{10} \mathrm{O}_{3} \mathrm{~N}_{4} \mathrm{~S}_{2}: \mathrm{C}, 40.27 ; \mathrm{H}, 3.38 ; \mathrm{N}, 18.79 ; \mathrm{S}$, 21.46. Found: C, 40.27; H, 3.15; N, 18.78; S, 21.25. UV absorption properties: $\lambda_{\max }^{\text {pH } 1} 251.5 \mathrm{~nm}(11500)$, $336 \mathrm{~nm}(31100) ; \lambda_{\max }^{\mathrm{pH}} 7249.5 \mathrm{~nm}(16300), 322.5 \mathrm{~nm}(25600) ; \lambda_{\max }^{\mathrm{pH} 13} 249.5 \mathrm{~nm}(19700), 320.5 \mathrm{~nm}(30800) . \quad \mathrm{PPC}:$ $R f$ (A) $0.62, R f$ (B) $0.19, R f$ (C) 0.38 .

8,3'-Anhydro-6,8-dimercapto-9- $\boldsymbol{\beta}$-D-xylofuranosylpurine-Dibenzoyl-8, $3^{\prime}$-cyclothioinosine (177 mg, $0.35 \mathrm{mmole})$ was dissolved in anhydrous methanol $(40 \mathrm{ml})$. Into this solution was added $2 \mathrm{~N}$ sodium methoxide $(0.2 \mathrm{ml})$. The reaction mixture was refluxed for $2 \mathrm{hr}$ with stirring. After completion of the reaction was checked by TLC, the mixture was worked up as described above. Recrystallization from water containing a small amount of thiosulfate gave colorless needles $(94.7 \mathrm{mg}, 90 \%)$. Analytical sample was recrystallized further from water, $\mathrm{mp}<300^{\circ}$. Anal. Calcd. for $\mathrm{C}_{10} \mathrm{H}_{10} \mathrm{O}_{3} \mathrm{~N}_{4} \mathrm{~S}_{2} \cdot 2 / 3 \mathrm{H}_{2} \mathrm{O}: \mathrm{C}, 38.71 ; \mathrm{H}, 3.65$; $\mathrm{N}, 18.06 ; \mathrm{S}, 20.65$. Found: C, 38.38; H, 3.44; N, 17.90; S, 20.27. UV absorption properties: $\lambda_{\mathrm{max}}^{\mathrm{pH}} 256$ $\mathrm{nm}(12300), 329 \mathrm{~nm}(\mathrm{sh}, 26200), 338.5 \mathrm{~nm}(31000) ; \lambda_{\max }^{\mathrm{pH}} 255 \mathrm{~nm}(13600), 327 \mathrm{~nm}(23100), 339 \mathrm{~nm}(\mathrm{sh}, 16800)$; $\lambda_{\max }^{\text {pH }} 13257 \mathrm{~nm}(14600), 314 \mathrm{~nm}(\mathrm{sh}, 21300), 325.5 \mathrm{mn}(25100)$. PPC: $R f(\mathrm{~A}) 0.59, R f(\mathrm{~B}) 0.12, R f(\mathrm{C}) 0.43$.

8,5'-Anhydro-6,8-dimercapto-9- $\beta$-D-ribofuranosylpurine_Dibenzoyl-8,5'-S-cyclothioinosine (152 mg, $0.3 \mathrm{mmole}$ ) was dissolved in methanol $(80 \mathrm{ml})$, which was previously saturated with dry ammonia at $0^{\circ}$. The reaction mixture was kept at $22^{\circ}$ for 5 days. After completion of the reaction was checked by TLC (Avicel, pH 10), methanol and ammonia were carefully evaporated. Residue was recrystallized from water containing a small amount of sodium thiosulfate to give pale yellow needles ( $86 \mathrm{mg}, 82 \%$ ). Analytical sample was recrystallized further from water, $\mathrm{mp} 279-283^{\circ}$ (decomp.). Anal. Calcd. for $\mathrm{C}_{10} \mathrm{H}_{10} \mathrm{O}_{3} \mathrm{~N}_{4} \mathrm{~S}_{2}$ : C, 40.27 ; H, 3.38; N, 18.79; S, 21.46. Found: C, 40.03; H, 3.16; N, 18.32; S, 21.66. UV absorption pro- 
perties: $\lambda_{\max }^{\text {pH } 1} 260 \mathrm{~nm}(9100), 329 \mathrm{~nm}(\mathrm{sh}, 28800), 338 \mathrm{~nm}(31800) ; \lambda_{\max }^{\mathrm{pH}} 7260 \mathrm{~nm}$ (10500), $329 \mathrm{~nm}(25300)$, $338 \mathrm{~nm}$ (sh, 21800); $\lambda_{\max }^{\mathrm{pH} 13} 259.5 \mathrm{~nm}(14400), 319 \mathrm{~nm}(\mathrm{sh}, 23700), 326 \mathrm{~nm}(25300)$. PPC: Rf (A) $0.47, R f$ (B) $0.17, R f(\mathrm{C}) 0.23$.

Disulfide of 8,2'-Anhydro-6,8-dimercapto-9- $\beta$ - $\left(3^{\prime}, 5^{\prime}\right.$-di-0-benzoyl-D-arabinofuranosyl)purine-Dibenzoyl-8,2'-S-cyclothioinosine (X) (5 mg, $0.01 \mathrm{mmole})$ was dissolved in hot ethanol $(20 \mathrm{ml})$. After cooling to room temperature, $1 \mathrm{~N}$ iodine solution $(10 \mu \mathrm{l})$ was added with stirring the solution. The reaction mixture was kept at room temperature for $30 \mathrm{~min}$, the ethanol evaporated in vacuo, and the residue was applied to a silica gel thin-layer chromatography. Elution with $\mathrm{CHCl}_{3}$-ethanol $(19: 1$, vol/vol) gave a band having $R f$ 0.47. UV absorption properties: $\lambda_{\max }^{\mathrm{H}^{-}} 232,296(\mathrm{sh}), 308 \mathrm{~nm} ; \lambda_{\max }^{\mathrm{EtOH}} 232,296(\mathrm{sh}), 308 \mathrm{~nm} ; \lambda_{\max }^{\mathrm{OH}-} 251,325 \mathrm{~nm}$.

Disulfide of 8,3'-Anhydro-6,8-dimercapto-9- $\beta$ - $\left(2^{\prime}, 5^{\prime}-0\right.$-dibenzoyl-D-xylofuranosyl)purine-Dibenzoyl-8,$3^{\prime}$-S-cyclothioinosine (XI) (5 mg, $\left.0.01 \mathrm{mmole}\right)$ was dissolved in hot ethanol $(20 \mathrm{ml})$. Into this solution was added $1 \mathrm{~N}$ iodine solution $(10 \mu \mathrm{l}, 0.005 \mathrm{mmole})$ and treated as described above. The disulfide was obtained by TLC from a band having $R f 0.45$ in solvent, $\mathrm{CHCl}_{3}$-ethanol $(19: 1$, vol/vol). UV absorption properties: $\lambda_{\max }^{\mathrm{H} *} 232,302(\mathrm{sh}), 312 \mathrm{~nm} ; \lambda_{\max }^{\mathrm{EtOH}} 231.5(\mathrm{sh}), 302(\mathrm{sh}), 312 \mathrm{~nm} ; \lambda_{\max }^{\mathrm{OH}-} 263.5,331.5 \mathrm{~nm}$.

Disulfide of 8,5'-Anhydro-6,8-dimercapto-9- $\beta$ - $\left(\boldsymbol{2}^{\prime}, 3^{\prime}\right.$-0-dibenzoyl-D-ribofuranosyl)purine-Dibenzoyl-8,$5^{\prime}$-S-cyclothioinosine (XII) $(5 \mathrm{mg}, 0.01 \mathrm{mmole})$ was dissolved in hot ethanol $(20 \mathrm{ml})$. Into this solution was added $1 \mathrm{~N}$ iodine $(10 \mu \mathrm{l}, 0.005 \mathrm{mmole})$ and treated as described above. Disulfide was obtained from a TLC band having $R f 0.45$ in $\mathrm{CHCl}_{3}$-ethanol (19:1, vol/vol) solvent. UV abosrption properties: $\lambda_{\max }^{\mathrm{H*}} 231$ $(\mathrm{sh}), 302(\mathrm{sh}), 312.5 \mathrm{~nm}$; $\lambda_{\max }^{\mathrm{EtOH}} 231$ (sh), $302(\mathrm{sh}), 312.5 \mathrm{~nm} ; \lambda_{\max }^{\mathrm{OH}-} 264,333 \mathrm{~nm}$.

Disulfide of 8,2'Anhydro-6,8-dimercapto-9- $\boldsymbol{\beta}$-D-arabinofuranosyl-purine-The procedure was essentially same as described in the literature. $\left.{ }^{14}\right) \quad 8,2^{\prime}$-S-cyclothioinosine ( $\left.3 \mathrm{mg}, 0.01 \mathrm{mmole}\right)$ was dissolved in hot $0.01 \mathrm{~m}$ phosphate buffer $(\mathrm{pH} 7.6,3 \mathrm{ml})$. After cooling to room temperature, $1 \mathrm{~N}$ iodine solution (10 $\mu 1$, $0.005 \mathrm{mmole}$ ) was added dropwise to the solution with stirring. The reaction mixture became turbid and finally to a gel. Precipitates were collected by centrifugation, washed with water three times, then with ether-alcohol $(1: 1, \mathrm{vol} / \mathrm{vol})$ mixture. Solid material was collected by centrifugation, dried over $\mathrm{P}_{2} \mathrm{O}_{5}$ at $60^{\circ}$ for $2 \mathrm{hr}$ in vacuo, and recrystallized from $n$-propanol. UV abosorption properties: $\lambda_{\max }^{\mathrm{H}^{*}}$ 226.5, 297 (sh), $310 \mathrm{~nm} ; \lambda_{\max }^{\mathrm{EtOH}} 226.5,297(\mathrm{sh}), 309 \mathrm{~nm} ; \lambda_{\max }^{\mathrm{OH}}{ }^{-} 253,313(\mathrm{sh}), 326 \mathrm{~nm}$.

Disulfide of 8,3'-Anhydro-6,8-dimercapto-9- $\beta$ - $\mathrm{D}$-xylofuranosyl-purine- $-8,3^{\prime}$-S-Cyclothioinosine ( $3 \mathrm{mg}$, $0.01 \mathrm{mmole})$ was dissolved in $0.01 \mathrm{~m}$ phosphate buffer $(\mathrm{pH} 7.6,3 \mathrm{ml})$. In to the solution was added $1 \mathrm{~N}$ iodine solution $(10 \mu \mathrm{l}, 0.005 \mathrm{mmole})$. Reaction was carried out as described above. Disulfide was recrystallized from $n$-PrOH. UV absorption properfies: $\lambda_{\max }^{\mathrm{H}^{+}} 225.5,301.5(\mathrm{sh}), 313.5 \mathrm{~nm} ; \lambda_{\max }^{\mathrm{EtoH}} 226,302(\mathrm{sh}), 313.5 \mathrm{~nm}$; $\lambda_{\max }^{\mathrm{OH}^{-}} 263,330 \mathrm{~nm}$.

Disulfide of 8,5'-Anhydro-6,8-dimercapto-9- $\beta$-D-ribofuranosyl-purine - $-8.5^{\prime}$-S-Cyclothioinosine (3 $\mathrm{mg}, 0.01 \mathrm{mmole})$ was dissolved in $0.01 \mathrm{~m}$ phosphate buffer $(3 \mathrm{ml})$ and oxidized with $1 \mathrm{~N} \mathrm{I}_{2}$ solution (10 $\mu 1,0.005$ mmole). Disulfide was recrystallized from $95 \%$ ethanol. UV absorption properties: $\lambda_{\max }^{\mathrm{H}^{*}} 224,303$ (sh), $315 \mathrm{~nm} ; \lambda_{\max }^{\mathrm{so \%}}{ }^{\mathrm{EtOH}} 223.4,303(\mathrm{sh}), 314.5 \mathrm{~nm} ; \lambda_{\max }^{\mathrm{OH}} \mathbf{2} 264,331.5 \mathrm{~nm}$.

Reduction of Disulfides with $\mathrm{NaS}_{2} \mathrm{O}_{4}-\mathrm{A}$ small amount of disulfide was dissolved in $50 \%$ EtOH in a UV cuvette and reduced with $0.01 \mathrm{~N} \mathrm{Na}_{2} \mathrm{~S}_{2} \mathrm{O}_{4}$ solution. Following the change in UV absorption showed completed conversion to 6-mercapto derivatives.

Acknowledgement This work was supported by Grant-in-Aid for Scientific Research from the Ministry of Education. We wish to thank to members of analysis room of Takeda Chemical Co. for elemental analyses and NMR measurements.

14) I.L. Doerr, I. Wempen, D.A. Clarke and J.J. Fox, J. Org. Chem., 26, (1961). 